\title{
Pattern of rheumatoid arthritis in West Malaysia
}

\author{
B. H. TOH*, S. SENGUPTA, A. H. ANG, J. C. White, AND K. S. LAU \\ From the Departments of Medicine, Orthopaedic Surgery, Radiology and Pathology, Faculty of Medicine, \\ University of Malaya, Kuala Lumpur, Malaysia
}

Common diseases are subject to considerable variation in incidence and expression due to influence of geographical factors, and rheumatoid arthritis (RA) is an example of this. Greenwood (1969) indicated that RA in tropical Africa is more benign than in temperate climates. In West Malaysia the severity and incidence appear to be intermediate between that in tropical Africa and in the temperate zones. Environmental, ethnic, and social factors interact in determining the pattern. Furthermore, the condition occurs at equivalent incidence with other rheumatic disorders, particularly gout and autoimmune disease as systemic lupus erythematosus (SLE). This report is a study of RA in the three main ethnic groups in West Malaysia.

\section{Material and methods}

The 57 patients attended the Arthritis Clinic, University Hospital, Kuala Lumpur, during 1967-70 and satisfied American Rheumatism Association criteria of 'definite'. RA (Ropes, Bennett, Cobb, Jacox, and Jessar, 1959). A further 21 cases of 'probable' RA have been excluded.

\section{Joints}

In the clinical assessment, the joints were examined according to the method of Beetham, Polky, Slocomb, and Weaver (1965).

\section{Laboratory investigations}

(1) Haematology (Dacie and Lewis, 1968).

(2) Urine analysis.

(3) Stool for ankylostomiasis.

(4) Serum proteins, uric acid, and blood urea.

(5) Serology: Waaler-Rose, latex-fixation for rheumatoid factor (RF, Hyland), antistreptolysin-O titre (Difco), LE cell, and blood Kahn tests.

The Waaler-Rose test was done according to the method of Dacie and Lewis (1968). The latex-fixation test with human gamma-globulin for RF was performed on a 1 in 20 serum dilution as a slide screen at room temperature $\left(c a .25^{\circ} \mathrm{C}\right.$.), and positive sera inactivated by heating at $56^{\circ} \mathrm{C}$. for $30 \mathrm{~min}$. (Dequeker, Van Noyan, and Vandepitte, 1969) and titrated on slides. The LE cell test was performed by the method of Zinkham and Conley (1956), with $80 \times 12 \mathrm{~mm}$. heparinized plastic tubes containing $8 \mathrm{ml}$. blood and twelve glass beads of 2-3 mm. diameter, rotated at 33 r.p.m. for $20 \mathrm{~min}$. and then maintained at room temperature for $20 \mathrm{~min}$. before separation of the buffy coat.

(6) Radiology of hands, chest, and all involved joints.

(7) Electrocardiogram.

(8) Synovial biopsy.

\section{Social background}

Of the patients with definite RA, the male patients were predominantly semi-skilled and unskilled workers. Most of the females were housewives from similar social groups, less than one-third coming from a skilled working background, and four were from professional families. Twothirds of the patients were from Kuala Lumpur, and most of the remainder from provincial towns, with only four from rural areas.

\section{Controls}

Blood and serum samples were obtained from medical students and the inhabitants of various rural and semirural areas.

\section{Results}

Table I shows the number of patients with RA. Compared with other joint conditions, RA and gout provided the majority of patients. Data on rheumatic fever, and septic, tuberculous, and post-traumatic arthritis have been excluded. Out of 53 patients with SLE seen during the period of this study, 35 had joint symptoms (Table I, overleaf).

Of the 57 patients with definite RA, 27 were Chinese, 17 Indians, and 13 Malays (Table II). Female preponderance was noted in all three ethnic groups, the overall ratio being $4 \cdot 2$ to 1 . The age at onset is shown in Fig. 1. In most patients the illness started when they were between 26 and 65 years. At presentation they had been ill for periods from a few weeks to 21 years: 29 for up to 1 year, seventeen for 2 to 5 years, and eleven for more than 5 years. A history of morning stiffness was given in almost all instances. 
Table I Distribution of patients with joint diseases seen in the Arthritis Clinic of the University Hospital, 1967 to 1970

\begin{tabular}{lcc}
\hline Diagnosis & $\begin{array}{c}\text { No. of } \\
\text { Patients }\end{array}$ \\
\cline { 3 - 3 } Rheumatoid arthritis Definite & 57 \\
Probable & & 21 \\
Gout & 62 \\
Systemic lupus erythematosus with joint & & 35 \\
symptoms & 25 \\
Polyarthralgia of unknown aetiology & 23 \\
Still's disease & 8 \\
Acute tropical polyarthritis & 6 \\
Psoriatic arthritis & 4 \\
Ankylosing spondylitis & \multicolumn{1}{c}{ Total } & 241 \\
\hline
\end{tabular}

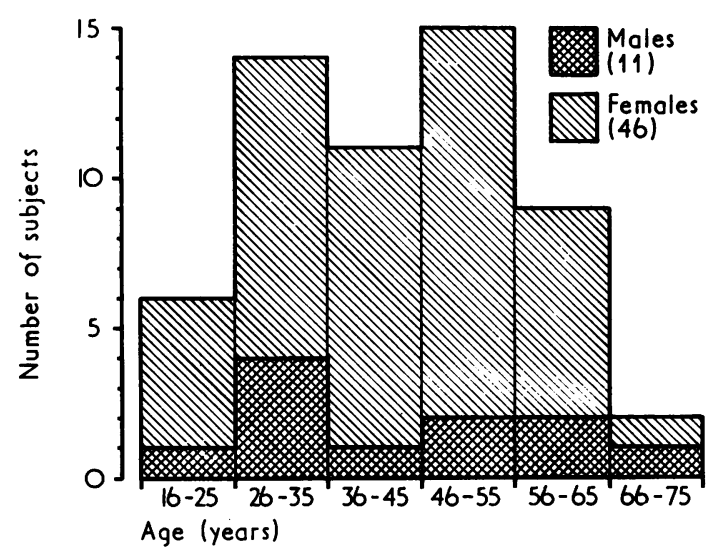

FIG. 1 Age of patients with definite rheumatoid arthritis on presentation at the hospital

\section{Articular manifestations}

The joints most frequently involved were wrist, proximal interphalangeal, knee, metacarpophalangeal, ankle, and elbow. Spindling of the fingers was noted fairly commonly where the proximal interphalangeal joints were involved, and hand deformities in fourteen cases. There were no significant differences between the three ethnic groups. The functional grade
Table II Patients with definite rheumatoid arthritis distributed by ethnic group and sex related to total hospital admissions, 1967-1970

\begin{tabular}{|c|c|c|c|c|c|}
\hline \multirow[t]{2}{*}{ Race } & \multicolumn{3}{|l|}{ Sex } & \multirow{2}{*}{$\begin{array}{l}\text { No. of } \\
\text { admissions }\end{array}$} & \multirow{2}{*}{$\begin{array}{l}\text { Ratio of cases } \\
\text { to admissions }\end{array}$} \\
\hline & Male & Female & Total & & \\
\hline $\begin{array}{l}\text { Chinese } \\
\text { Indians } \\
\text { Malays }\end{array}$ & $\begin{array}{l}4 \\
3 \\
4\end{array}$ & $\begin{array}{r}23 \\
14 \\
9\end{array}$ & $\begin{array}{l}27 \\
17 \\
13\end{array}$ & $\begin{array}{r}20,217 \\
9,621 \\
5,408\end{array}$ & $\begin{array}{l}1: 749 \\
1: 566 \\
1: 416\end{array}$ \\
\hline Total & 11 & 46 & 57 & 35,246 & $1: 618$ \\
\hline
\end{tabular}

and activity of arthritis is compared with Scottish (Duthie, Thompson, Weir, and Fletcher, 1955) and Nigerian (Greenwood, 1969) patients in Table III.

\section{Extra-articular manifestations}

No rheumatoid nodules were seen in this series. Small subcutaneous nodules just distal to the olecranon in three patients were fibro-fatty tissue on biopsy. Hepatomegaly occurred in ten patients, with one in congestive cardiac failure, splenomegaly in five, and palpable cervical lymph nodes in one. Fever was usually absent, and mild when present. Systemic RA (Schmid, Cooper, Ziff, and McEwen, 1961) occurred in a Chinese patient with digital vasculitis an gangrene of the finger tips and toes, mixed sensori motor neuropathy with wrist and foot drop, peric carditis, episcleritis, and scleromalacia perforans.

\section{Associated diseases}

Five patients had ankylostomiasis with anaemia. Three others were diabetic, and eight were hypertensive. Two post-menopausal females had ischaemic heart disease. Two patients had Bell's palsy, two bronchial asthma, one pulmonary tuberculosis, and one glaucoma. No clinical or laboratory evidence of malaria was encountered.

\section{Haematological investigations}

Haemoglobin values ranged from 4.0 to $15.5 \mathrm{~g}$. per $100 \mathrm{ml}$. (mean 11.6). Eleven had values less than 10.1 g. per $100 \mathrm{ml}$, three having ankylostomiasis. The total white cell count ranged from 4.000 to 19,500 per $\mu$ l. (mean 7,900 ), neutrophils 2,600 to 15,600 per $\mu$ l.

Table III Percentage distribution of functional class and activity at the time of presentation. A comparison between Scots, Nigerians, and Malaysians

Functional grading and activity according to Duthie and others (1955).

\begin{tabular}{|c|c|c|c|c|c|}
\hline \multicolumn{3}{|l|}{ Race } & \multirow{2}{*}{$\begin{array}{l}\text { Scottish } \\
\text { (Duthie and others, 1955) } \\
0 \\
35 \\
43 \\
22\end{array}$} & \multirow{2}{*}{$\begin{array}{l}\begin{array}{l}\text { Nigerian } \\
\text { (Greenwood, 1969) }\end{array} \\
6 \\
28 \\
44 \\
22\end{array}$} & \multirow{2}{*}{$\begin{array}{l}\text { Malaysian } \\
14 \\
20 \\
25 \\
41\end{array}$} \\
\hline Functio & al grade & $\begin{array}{l}\text { I } \\
\text { II } \\
\text { III } \\
\text { IV }\end{array}$ & & & \\
\hline Activity & \multicolumn{2}{|c|}{$\begin{array}{l}\text { Inactive } \\
\text { Moderately active } \\
\text { Very active }\end{array}$} & $\begin{array}{l}10 \\
63 \\
26\end{array}$ & $\begin{array}{l}1 \\
67 \\
32\end{array}$ & $\begin{array}{r}4 \\
56 \\
40\end{array}$ \\
\hline
\end{tabular}


(mean 5,200). The erythrocyte sedimentation rate (Westergren) varied from 5 to $139 \mathrm{~mm}$. in one hour (mean 73). No significant differences occurred between the three ethnic groups.

\section{Biochemical investigations}

The distribution of serum albumin in 48 patients and of serum gama globulin in 26 is shown in Fig. 2 as compared with normal students. One patient had a cryoglobulin fraction (IgM). Serum uric acid was determined in 51 patients; nine had marginally raised values ranging from $6 \cdot 1$ to $9 \cdot 3 \mathrm{mg}$. per $100 \mathrm{ml}$., one being in chronic renal failure. Mean blood urea in fifty patients was $27 \mathrm{mg}$. per $100 \mathrm{ml}$. In forty patients mean serum iron ( $80 \mu \mathrm{g}$. per $100 \mathrm{ml}$.) and percentage iron saturation ( 25 per cent.) were low, although the mean unsaturated iron-binding capacity $(237 \mu \mathrm{g}$. per $100 \mathrm{ml}$.) and total iron-binding capacity (317 $\mu \mathrm{g}$. per $100 \mathrm{ml}$.) were within normal limits. The mean serum folic acid was $7.6 \mathrm{ng}$. per ml., but ranged from 3.4 to 26. Mean serum vitamin $B_{12}$ level was normal at 685 pg. per ml.

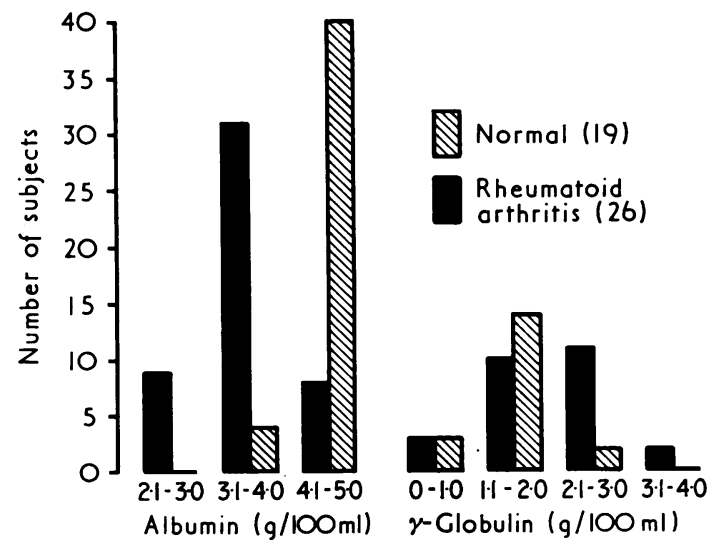

FIG. 2 Serum albumin and gamma globulin levels. Frequency distribution in normal persons (students) and patients with rheumatoid arthritis

\section{Immunological investigations}

The results of Waaler-Rose, latex fixation for RF, and LE cell tests are shown in Table IV. A clinically significant positive Waaler-Rose test was taken as a titre of $1: 32$ or more, and latex fixation as $1: 160$ or more. The proportion of positive results for RF and the LE cell test in the Chinese was greater than for the other ethnic groups. Antistreptolysin-O titres ranged from 50 to greater than 2,500 Todd units (mean 370) for 32 patients with RA. The blood Kahn test in 32 instances was negative.

No positive Waaler-Rose test was encountered in 66 medical students. In a group of 81 , one positive latex-fixation test $(1: 320$ after heating) was obtained (1.2 per cent.). The antistreptolysin- $O$ titres ranged from 12 to 250 in 32 normal students and blood donors (mean 106). In a group of forty rural and semi-rural individuals of the various races, aged 11 to 61 years (mean 31), no positive Waaler-Rose test was encountered. The latex test was positive at a 1 in 20 dilution in two, and at 1 in $\mathbf{4 0}$ in one individual, but no higher titres were found. The antistreptolysin-O titres ranged from 50 to 625 Todd units (mean 245). The total serum globulins ranged from $2 \cdot 7$ to $6 \cdot 2$ g. per $100 \mathrm{ml}$. (mean $4 \cdot 2$ ). Malaria is a common infection in the area from which these individuals were drawn.

\section{Radiological studies of joints}

Radiological grading of hands (Kellgren, Jeffrey, and Ball, 1963) was available in 49 patients. 88 per cent. were divided equally between Grades $0-1$ and 2, with 10 per cent. in Grade 3, and 2 per cent. in Grade 4. Greenwood (1969) found a similar preponderance of less severe changes, in contrast to the English series of Thould and Simon (1966) with which he compared them. No significant differences were noted between the three main ethnic groups in Malaysia. Erosions were seen most commonly in the metacarpophalangeal and proximal interphalangeal joints and in decreasing order of frequency in the bases of the metacarpals, ulnar styloid, and lower end of ulna. Bony ankylosis involving the wrists, carpus, and carpometacarpal joints were seen in three Chinese and one Indian. Radiography of the sacroiliac joints suggested chronic inflammatory change in one out of 21 examinations.

Table IV Waaler-Rose test, latex-fixation test for rheumatoid factor, and LE cell test in patients with definite rheumatoid arthritis

\begin{tabular}{|c|c|c|c|c|c|c|c|c|c|}
\hline \multirow[t]{3}{*}{ Race } & \multicolumn{3}{|c|}{ Waaler-Rose test } & \multicolumn{3}{|c|}{ Latex-fixation test } & \multicolumn{3}{|c|}{$L E$ cell test } \\
\hline & \multirow{2}{*}{$\begin{array}{l}\text { No. } \\
\text { tested }\end{array}$} & \multicolumn{2}{|c|}{ Positive $>1: 32$} & \multirow{2}{*}{$\begin{array}{l}\text { No. } \\
\text { tested }\end{array}$} & \multicolumn{2}{|c|}{ Positive $>1: 160$} & \multirow{2}{*}{$\begin{array}{l}\text { No. } \\
\text { tested }\end{array}$} & \multicolumn{2}{|c|}{ Positive } \\
\hline & & No. & $\%$ & & No. & $\%$ & & No. & $\%$ \\
\hline $\begin{array}{l}\text { Chinese } \\
\text { Indians } \\
\text { Malays }\end{array}$ & $\begin{array}{l}24 \\
13 \\
10\end{array}$ & $\begin{array}{l}7 \\
1 \\
1\end{array}$ & $\begin{array}{r}29 \\
8 \\
10\end{array}$ & $\begin{array}{r}15 \\
9 \\
9\end{array}$ & $\begin{array}{l}8 \\
2 \\
1\end{array}$ & $\begin{array}{l}53 \\
22 \\
11\end{array}$ & $\begin{array}{l}20 \\
13 \\
11\end{array}$ & $\begin{array}{l}5 \\
0 \\
1\end{array}$ & $\begin{array}{r}25 \\
0 \\
9\end{array}$ \\
\hline Total & 47 & 9 & 19 & 33 & 11 & 33 & 44 & 6 & 14 \\
\hline
\end{tabular}




\section{Synovial histopathology}

This was obtained in eleven patients (four synovial biopsies and seven synovectomies). Proliferative changes were seen in all, with synovial hyperplasia, villous formation, and infiltration by polymorphs, lymphocytes, mononuclear, and plasma cells, consistent with chronic nonspecific synovitis; they were rather uniform in seven cases, but more severe in two, with presence of fibrinoid necrosis in one, and mild in another two.

\section{Discussion}

Rheumatoid arthritis is not an uncommon disease in West Malaysia, and together with gout is a major cause of joint disability.

The age distribution shows the majority in the 26 to 65 year range. In West Nigeria (Greenwood, 1969) there was preponderance of younger patients (21 to 40 years) and no distinct sex predominance. Our patients were predominantly female as in Britain (Kersley, 1962) and Japan (Schichikawa, 1968). The distribution of RA does not differ significantly among the three main ethnic groups. Unlike the situation in the United Kingdom (Sze, 1963) with most of the patients being over the age of 45 , more than half our cases are below this age. This may be related to the marked preponderance of younger people in the population (Vital Statistics, West Malaysia, 1968), who are exposed to the tropical environment where multiple infections are common. Whereas Greenwood (1968) encountered relatively few cases of SLE in Western Nigeria, 53 cases were seen here during the period of study; these will be reported in a separate paper.

The frequency of RA, with one case in 618 hospital admissions, appears higher than in tropical West Africa, where Greenwood (1969) found an incidence of only 1 in 2,344 admissions over a 10-year period. This may be due partly to the tendency for patients with a chronic disease to seek treatment at a new hospital. Nonetheless the incidence is lower than in the United Kingdom, where Sze (1963) found an incidence of 1 in 125 of total hospital discharges and deaths from all causes, based on the 1957 hospital inpatients' inquiry. Figures from general practice indicate a higher incidence in the general population of the United Kingdom, increasing with age (Sze, 1963; Lawrence, 1963). In the Osaka district in Japan, Shichikawa (1966) reported RA in 1 in 167 of the 45 to 64 age group. Articular manifestations were marked by a good deal of functional disability (Table III), although radiological changes were mild. About half of the patients had had the disease for 2 to 21 years before attendance.

In contrast to a 30 per cent. incidence in a British series (Thompson, 1965), subcutaneous rheumatoid nodules were not seen. Chest $x$ rays revealed no rheumatoid lung disease. Splenomegaly was occasionally found, but malaria is still common in Malaysia. Visceral manifestations of RA were seen in two Chinese females.

The incidence of positive Waaler-Rose and latex- $\overrightarrow{\bar{B}}$ fixation tests was low in controls of medical students $\bar{c}$ and rural subjects. Lim and Leong (1967) found an incidence of 2.3 per cent. of positive Waaler-Rose tests in 798 urban Malaysians, and in about one-third of the seropositive individuals clinical evidence of arthritis was found. Our patients with RA showed a higher proportion of positive results (Waaler-Rose 19 per cent. positive and latex fixation 33 per cent. positive). Heterophil antibodies against sheep red cells are rarely encountered here, and the WaalerRose test appears suitable for the detection of RF. Greenwood, Muller, and Valkenburg (1971) have shown that, in Nigeria, where heterophil antibodies are encountered frequently at high titre, the human erythrocyte agglutination test is more reliable. In the apparently normal Nigerian population, Valkenburg (1963) and Greenwood (1969) found a high incidence of positive latex-fixation tests, and the latter commented that this test might have limited diagnostic value. RF with selective affinity for human gamma globulin is prevalent at high titre in the oldes Nigerian population (Greenwood and others, 1971) which may result from the cumulative effects of variety of infections rather than from malaria alone Curtain, Kidson, Champness, and Gorman (1964) have stressed the role of cumulative, multiple infections in the causation of high gamma globulins in New Guinea, and the interpretation of positive tests for RF should be made with caution in that region (Wells, 1967). Our own experience with rural Malaysian populations, where malaria is quite a common infection, is consistent with these views. Even in temperate zones, the significance of serological tests in population studies is difficult to evaluate (de Graaff, Laine, and Lawrence, 1963; Hijmans, 1963; Valkenburg, 1963), although Glynn (1968) gives an incidence of only 2 to 5 per cent. of positive reactions for RF in non-rheumatoid subjects, and Duthie (1969) finds 85 per cent. of positive reactions in established RA. The complexity of the pattern of disturbed immunoglobin production in RA has been reviewed by Waller (1971).

LE cell tests were positive in 14 per cent. in this series. The significance in RA has been reviewed by Duthie (1969), and he indicated that such cases were not necessarily more likely to develop frank SLE. The ultimate course of the RA may be more severe, however, in those cases showing positive tests for LE cells (Hazevoet, Hijmans, and Kievits, 1966) and antinuclear factor (Duthie, 1969).

Trowell (1960) found raised serum gamma globulins and erythrocyte sedimentation rates in apparently normal African communities, and Tint (1971) 
reported occasional high ESR values in otherwise healthy Burmese, especially females; our experience with medical students is similar. Saha and Banerjee (1971) found a positive correlation of ESR with globulin level, especially the gamma globulins, which could be a factor in causing high ESR in the tropics.

The anaemia of RA is usually normocytic, hypochromic, with lowered serum iron, TIBC, and transferrin saturation, but decrease in marrow sideroblasts and normal or increased reticuloenthelial iron (Cartwright and Lee, 1971). The overall pattern of our anaemic patients conforms to this. Gough, McCarthy, Read, Mollin, and Waters (1964) found that patients with RA may develop megaloblastic anaemia through deficiency of, or increased requirements for, folate. Nine out of 37 of our patients had serum folate levels below $5 \mathrm{ng}$. per $\mathrm{ml}$., and in three with haemoglobin levels below $10 \mathrm{~g}$. per $100 \mathrm{ml}$. both iron and folate values were low.

Greenwood (1968) suggested that the benign nature of tropical rheumatoid arthritis may be related to immunological changes induced by parasites, particularly malaria. However, SLE is particularly common in the Chinese here, and Tay and Khoo $(1970,1971)$ have found the same in Singapore. The serological changes (RF and LE cells) are also more frequent in the Chinese, suggesting that both genetic and environmental factors may influence the disease.

\section{Summary}

In West Malaysia RA appears to be less common than in temperate climates, but more common than in tropical Africa; furthermore, the incidence of gout and SLE is comparable. The clinical manifestations of RA are milder than those seen in more temperate climates. Subcutaneous rheumatoid nodules have not been observed.

Positive serological tests for RF are significantly higher than in the general Malaysian population, but still lower than those reported for patients with RA in temperate climates. Of the three main ethnic groups, the highest incidence of positive results is found in the Chinese.

We thank Dr. H. O. Wong, Head of the Department of Medicine, Professor J. F. Silva, Head of the Orthopaedic Department, Mr. G. L. Chan, F.I.M.L.T., and Mr. K. H. Yee and the staff of the Nutritional Anaemia Research Laboratory, for co-operation and assistance; the General Manager and Dr. B. Freeman of Pahang Consolidated Co. Ltd., Sungei Lembing, for facilities to obtain control blood samples. This study was supported in part by funds from the United States Public Health Service Grant AM11048. One of us (J. C. W.) is in receipt of a Special Commonwealth Award.

\section{References}

Beetham, W. P., Polky, H. F., Slocumb, C. H., and Weaver, W. F. (1965) 'Physical Examination of the Joints'. Saunders, New York

CARTWRight, G. E., AND LeE, G. R. (1971) Brit. J. Haemat., 21, 147 (Annotation: the anaemia of chronic disorders)

Curtain, C. C., Kidson, C., Champness, D. L., AND Gorman, J. G. (1964) Nature (Lond.), 203, 1366 (Malaria antibody content of gamma ${ }_{2}-7 \mathrm{~S}$ globulin in tropical populations)

DACIE, J. V., AND LEWIS, S. M. (1968) 'Practical Haematology'. 4th ed. Churchill, London

DE GRAAFF, R., LAINE, V., AND LAWRENCE, J. S. (1963) 'Comparison of surveys in various northern European countries', in 'Epidemiology of Chronic Rheumatism', vol. 1, p. 228, ed. J. H. Kellgren, M. R. Jeffrey, and J. Ball. Blackwell, Oxford

Dequeker, J., Van Noyen, R., AND Vandepitte, J. (1969) Ann. rheum. Dis., 28, 431 (Age-related rheumatoid factors. Incidence and characteristics)

DuthIE, J. J. R. (1969) 'Rheumatoid arthritis', in 'Textbook of the Rheumatic Diseases', ed. W. S. C. Copeman, 4th ed., p. 259. Livingstone, Edinburgh and London

—, ThOMPSON, M., WeIR, M. M., AND FleTCher, W. B. (1955) Ann. rheum. Dis., 14, 133 (Medical and social aspects of the treatment of rheumatoid arthritis)

GlynN, L. E (1968) 'Rheumatoid arthritis', in 'Clinical Aspects of Immunology', ed P. G. H. Gell, and R. R. A. Coombs, 2nd ed., p. 848. Blackwell, Oxford

Gough, K. R., McCarthy, C., ReAd, A. E., Mollin, D. L., AND Waters, A. H. (1964) Brit. med. J., 1, 212 (Folic acid deficiency in rheumatoid arthritis)

GreENWOOD, B. M. (1968) Lancet, 2, 380 (Autoimmune disease and parasitic infections in Nigerians)

- (1969) Ann. rheum. Dis., 28, 488 (Polyarthritis in Western Nigeria. I. Rheumatoid arthritis)

-, Muller, A. S., AND VAlkenburg, H. A. (1971) Clin. exp. Immunol., 9, 161 (Rheumatoid factor in Nigerian sera)

Hazevoet, H. N., Hijmans, W., and Kievits, J. H. (1966) Ann. rheum. Dis., 25, 375 (Significance of the L.E. cell phenomenon for the symptomatology and prognosis of rheumatoid arthritis. A follow-up study of 9 years)

Hijmans, W. (1963) 'Validity of serological tests', in 'Epidemiology of Chronic Rheumatism', ed. J. H. Kellgren, M. R. Jeffrey, and J. Ball, vol. 1, p. 82. Blackwell, Oxford

Kellgren, J. H., Jeffrey, M. R., AND Ball, J. (ed.) (1963) 'Atlas of Standard Radiographs of Arthritis': ‘The Epidemiology of Chronic Rheumatism', vol. 2. Blackwell, Oxford

KeRSLEY, G. D. (1962) 'The Rheumatic Diseases', 4th ed. Heinemann, London 
Lawrence, J. S. (1963) Brit. J. clin. Pract., 17, 699 (Prevalence of arthritis)

Lim, T. W., AND LeONG, W. W. (1967) Med.J. Malaya, 22, 110 (A survey of the rheumatoid factor using the sheep cell agglutination test)

Ropes, M. W., Bennett, G. A., Cobb, S., Jacox, R., And Jessar, R. A. (1959) Ann. rheum. Dis., 18, 49 (1958 Revision of diagnostic criteria for rheumatoid arthritis)

SaHA, N., AND BANERJEe, B. (1971) Trop. geogr. Med., 23, 30 (Correlation of erythrocyte sedimentation rate with serum composition in the tropics)

Schmid, F. R., CoOPER, N. S., ZIFF, M., AND McEwen, C. (1961) Amer. J. Med., 30, 56 (Arteritis in rheumatoid arthritis)

ShichiKaWA, K. (1968) 'Prevalence of rheumatic diseases in Japan', in 'Population Study of the Rheumatic Diseases': Proceedings of the 3rd International Symposium, New York, 1966. National Institute of Arthritis and Metabolic Diseases and the Arthritis Foundation, ed. P. H. Bennett and P. H. N. Wood, p. 55. Int. Congress Series, 148. Excerpta Medica Foundation, Amsterdam and New York

SzE, T. S. (1963) 'Mortality and morbidity from chronic rheumatic diseases in the United Kingdom and Western Europe', in 'The Epidemiology of Chronic Rheumatism', ed. J. H. Kellgren, M. R. Jeffrey, and J. Ball, vol. 1, p. 1. Blackwell, Oxford

TAY, C. H., AND KHOO, O. T. (1970) Far East med.J., 6, 345 (The pattern of autoimmune diseases in Singapore)

- (1971) Singapore med.J.. 12, 92 (Systemic lupus erythematosus-an analytical study of eighty cases in Singapore)

Tномpson, M. (1965) 'The clinical features of rheumatoid disease', in 'Progress in Clinical Rheumatology', ed. A. St. J. Dixon, p. 10. Churchill, London

Thould, A. K., AND Simon, G. (1966) Ann. rheum. Dis., 25, 220 (Assessment of radiological changes in the hands and feet in rheumatoid arthritis)

TINT, K. (1971) 'E.S.R. standards in Burmese people', in 'Scientific Contributions, 2nd Meeting of the Asian and Pacific Division of the International Society of Haematology', Melbourne, p. 170

Trowell, H. C. (1960) 'Non-infective Disease in Africa'. Arnold, London

VALKENBURG, H. A. (1963) 'Rheumatoid factor in populations', in 'Epidemiology of Chronic Rheumatism', ed. J. H. Kellgren, M. R. Jeffrey, and J. Ball, vol. 1, p. 74. Blackwell, Oxford

Vital Statistics, West Malaysia (1968) Dept. of Statistics, Kuala Lumpur, p. 162

WALLER, M. (1971) 'Present status of the rheumatoid factor' in Chemical Rubber Company, Cleveland: Critical Reviews in Clinical Laboratory Sciences, 2, 173

WelLs, J. V. (1967) Med.J. Austr., 2, 777 (Positive results to serological tests for rheumatoid factor in New Guinea)

Zinkham, W. H., AND Conley, C. L. (1956) Bull. Johns Hopk. Hosp., 98, 102 (Some features influencing the formation of L.E. cells. A method of enhancing L.E. cell production) 